\title{
NATIONAL DEFENCE - ITS ROLE AND IMPORTANCE IN ENSURING THE IMAGE OF A STABLE STATE
}

\author{
Diana CHIȘ-MANOLACHE \\ dianamanolache88@yahoo.com \\ Ciprian CHIȘ \\ chis.ciprian@yahoo.com \\ MILITARY UNIT 02439, BUCHAREST, ROMANIA \\ “CAROL I” NATIONAL DEFENCE UNIVERSITY, BUCHAREST, ROMANIA
}

\begin{abstract}
By carrying out the national defence, national interests are protected by the active involvement of state institutions with responsibilities in the field, but not only these, being committed the available resources of the state in order to ensure the sovereignty, the independence, the unity, the territorial integrity and the constitutional democracy, under the conditions of combating any type of aggression. This is achieved through the full exercise of citizens' rights and freedoms, through conscious assumption of responsibilities, and by the affirming a state as an active member of the community and international organisations. The national defence is very well grounded, being regulated at national level by rules approved by the President of the country, by the Government, having the legal opinion of the Supreme Defence Council of the Country.One of the most important resources needed to achieve the national defence is the human resource that needs to be continuously prepared and trained through various forms of preparation. A high level human resource training determines a high level of a state national defence.
\end{abstract}

\section{KEYWORDS:}

National defence, security, aggression, human resources, international organisations

\section{Introduction}

The national defence must be carried out by legal means and has the primary role of protecting the citizen and the interests of that state. This is achieved through the active involvement of State institutions with responsibilities in the field, being used all its resources, in order to ensure independence, territorial integrity and democracy, in the conditions of combating any kind of aggression. By carrying out the national defence, there are assured, as we 
have previously mentioned, citizens' rights and freedoms, and the status of active member of the international community is also affirmed, by respecting the commitments made in the international organisations to which that State has acceded.

\section{The national defence}

Since antiquity and so far, we have been able to observe that the defence is an important form of struggle that seeks to stop the enemy's offensive, and represents several measures taken in order to realise its, while security (a newer concept compared to the defence) is a state of fact, of protection that you are at the shelter from any danger, a sense of trust and tranquility that somebody has when he is out of danger.

In addition, the national defence is the state, the general conception of a State under which national interests are defined, designed and promoted through the institutions empowered by the constitutionally applicable to this purpose. Throughout this process, all available resources at a given time are committed to ensuring the preservation of sovereignty, independence, unity, territorial integrity, constitutional democracy, and national interests under the conditions of facing any kind of aggression, danger, threat, risk or challenge.

The national defence aims to ensure the state of democratic normality to which the society, namely citizens, communities and the state, aspire, based on efforts that aim at the establishment of legality, economic growth, social balance and political stability. This is achieved through the full exercise of citizens' rights and freedoms, through the conscious assumption of responsibilities, and by affirming a state as an active member of the community and international organisations.

The national defence is a concept that has evolved over time, currently covering diverse domains. In the wider sense, the national defence designates "all measures and provisions of any kind adopted by a state, which has as its object the assurance, at any time, in any circumstance and against any form of aggression, of the security and the integrity of the territory, and also the life of the population" (Moştoflei \& Duţu, 2004, p. 8). In other words, this notion refers to the actions and to the measures that each individual State adopts in order to protect the lives of its citizens, its own property and national territory, and to guarantee independence.

In general, the national defence involves combating the possibility that what belongs to a state (population, territory, heritage, property, values, attributes, etc.) is threatened with the change of the status of the inmate up to a certain time. The national defence must keep in mind that the risks and threats, possible and probable, on one's rights and freedoms (individual, group, community and state) are in continuous transformation under the complex action of a wide range of social, economic, military, cultural factors, etc. On the other hand, if there is no risk or any real threat to anything or anyone within a state, it cannot be discussed and the notion of national defence of the State cannot be taken into question.

The documents that substantiate defence planning at national level should continue to be reminded. Thus, according to the provisions of Law No. 203 of the 16.07.2015 on defence planning, at national level, these documents are the following: The National Defence Strategy (2015) and The Governance Programme $(2017 ; 2018)$. The defence planning documents, at departmental level, are: the White Defence Charter (2017), The Military Strategy (2016), The Defence Planning Directive (2018) (The Directive has a time horizon of 10 years and is reviewed annually), The Major Programmes and The Operational Plans for the use of forces (managed by a program Director, who is the Head/the Master of a military structure and these are reviewed annually).

If we were to strictly refer to our country and given that, in the regional plan, 
Romania is a member state of the European Union, we could affirm that the national defence corroborated with the collective one is the whole of organisational and functional measures which, once have been adopted, are able to exclude the possibility of any threats or aggression of any kind.

Thus, given the position of Romania in international bodies, it is common ground that the above-mentioned visas were thus formulated to be in the context of the Treaty establishing a Constitution for Europe or those of United Nations Charter.

In this respect, under the abovementioned Treaty, the national defence of the Member States of the European Union is a part of the Union's common defence, which obliges that "if $a$ Member State were to be the subject of an armed aggression in its territory, the other Member States are obliged to provide aid and assistance by all means available to them" (The Chart of the United Nations Organisation, article 51, 1945, p. 9), with the mention that "this does not affect the specific nature of the security and defence policy of certain Member States" (The Chart of the United Nations Organisation, article 51, 1945, p. 9). In the same context, the application of the solidarity clause operates almost identically, according to which "if a Member State is the subject of a terrorist attack or a natural or man-made disaster, the other Member States shall offer assistance it at the request of the political authorities of the affected or concerned State" (The Establishing Treaty of a Constitution for Europe, 2004, p. 5).

If we refer to the exercise of national defence in the context of belonging to the North Atlantic Treaty Alliance, things are conceptually specified in the so-known Article 5 of the Washington Treaty: „The parties agree that any armed assault against one or more of them, which occurs in Europe or in North America, will be considered as an attack against all parties and, consequently, they agree that, if such an attack occurs, each of the parties, by exercising the right to self-defence, individual or collective, recognised by Article 51 of the Charter of the United Nations, to support the contested party or parties, by resorting, at the same time, individually and in agreement with the other parties, in any action it deems necessary, including the use of the armed force, for restoring and maintaining the security in the North Atlantic region" (North Atlantic Treaty, 1949, p. 1).

The application and the compliance of the provisions which refer to the necessity of exercising the collective defence are all the more necessary since, after the end of the cold War, the security environment has been and it is characterized by open borders, which could represent, at the same time, both a safety element and an element that can easily lead to unforeseen situations and implicit, at the very most imminent dangers. However, overall, we appreciate that "the opening of borders and the interconnection of civilational cultures has led to the progress of democracy, the flows of goods and investment, technological development and contributed to economic prosperity felt in the macro plan, micro plan, but also on a personal level" (Moştoflei \& Duţu, 2004, p. 5).

It is also important to specify that the national defence reflects a dynamic reality that has in its structure the following components: political, military, economic, civil, cultural, and psychological.

As it is normal, the political component of the national defence is the inaliable attribute of state leadership. It derives from the responsibility assumed by those who hold political power in the state, to the entire population on the protection of its life and property under any conditions. By this expression ("under any circumstances") it must be understood that the public authority bears the responsibility for ensuring the environment of life and activity of the citizens of the country, both at peace and in situations of crisis or war. The political component of the national defence includes 
all measures and actions that state leadership adopts and puts into practice, in all areas of activity both internally and externally in order to defend national interests, the life and the goods of the citizens. Between these measures there are, on the one hand, the strict political ones: pressures, sanctions, coercion, etc. both at the level of bilateral relations and by calling on the competent international organisations and, on the other hand, all other orders military, economic, diplomatic, cultural, etc. At the same time, the political side of national defence assume the next aspects: the political decision (the choice of an alternative and the accountability for this option); the public support (the capturing of the national consensus for the adopted political decision); the establishing of the political instruments that will be used in order to achieve the proposed goals.

The military component of the national defence is obviously the competence of the State army, and in fact it is the responsibility of the Army's force categories (Land forces, Air forces, Naval forces) and also, it is the responsibility of other structures such as: the Forces for Special Operations, the Logistics/ the Logistic Support Component, the Communications, Informatics and Information Technology Component etc. It has strategic objectives of discouraging the enemy's potential, to prevent hazards in order to guarantee fundamental interests, protection of the population, protection of the territory, etc.

The civilian component of the national defence is assured by the state's institutions empowered by law to protect its population and property. Of these, the most important and the most significant: the Ministry of Internal Affairs, the Emergency Inspectorate, the Romanian Gendarmerie, these institutions having as primary role to guarantee the individual security, the security of persons, the intervention in case of accidents and natural calamities, disasters, and ecological accidents. Also, the civil defence include the population protection measures against terrorist attacks, during which weapons of mass destruction are used. In the cases laid down by law, alongside these institutions, the Army is the institution which actively participates in the implementation of adopted measures in order to protect the lives of the population or to protect communities, and to implement measures on the salvation and protection of their assets and values.

The economic component of national defence is the responsibility of the state institutions that have competences established by specific laws in this field of activity. It aims the production, the movement and the way of using resources, the improving and the enhancing of national competitiveness in a globalised economy, the combating of illicit patent exploitation, the combating of counterfeit products (which may affect the economy of a state), the protection of databases and technological transfers, the fight against economic disinformation in the virtual, and informatics environment (which may also cause the uncertainty at the economic level).

Another component of the defence, namely the cultural one, involves the promotion of spiritual goods and romanian traditional values in the world, through specialised structures and through specific programmes that produce an positive international impact for the state that promotes them.

The psychological component of national defence, a defence component that seems less important at first sight, but with a high significance in the whole context of national defence, is organized for the purpose of maintaining and strengthening the will of the population and implicitly the state to resist and defeat any aggressor, in any kind of circumstance. It is usually carried out by specialised structures in such activities and actions, with the wide media competition. The information, namely its movement by adequate vectors, is the main way to achieve this type of defence.

So, in the light of the above exposed, we could say that the national defence is a phrase with a dynamic evolution as a result of its need for continuous adaptation to the daily reality which, in its turn, in a permanent change. 
The defense, through everything it represents, is characterized by complexity. It derives from its interaction with the society in which it is organised and it runs constantly, steadily and systematically. On the one hand, a set of different factors as nature and content (economic, social, political, psychosocial, cultural) acts on the national defence. On the other hand, it influences important areas of activity in society. An important factor of the previous reminded, which act on the defence, is the force of prejudices. Thus, for young people in particular, the defence is the subject of stereotypes and could lead either to the refusal to address and to understand the problem, or backwards, ,to an interest centered in a unique manner on the facts of arms" (Moştoflei \& Duţu, 2004, p. 11).

We must also say that the national defence implies the moral and physical commitment of the population, and the realization of the defence requires the acquisition of civic adhesion. Citizens must be very well informed of how they must contribute to achieving it. We mention that, in present, there are some deficiencies on this segment, and it is necessary to know on whose behalf and for what reason citizens should engage in a battle, going to need until the ultimate and supreme sacrifice. The most important thing that should be known by all citizens is the fact that the national defence is carried out under the flag of the country and in the name of preserving and protecting the national territory, its traditions, and its goods. The history of our country has proven that the population has manifested the commitment to the desire to have a free country, highlighting a superior motivation based on a strong affective support: patriotic attitudes and feelings, national pride, honor, etc.

\section{The place and the role of national defence in the allied context}

The last National Defense Strategy of Romanian State, the one related to the period 2015-2019, was elaborated on the basis that Romania is a member of both NATO and the EU, but also in relation to the last major international conflicts that have been triggered in the last decade, as well as major changes in the international security framework (e.g.: complex conflict in Syria with all kinds of complications, annexation of Crimea in 2014 by Russia, the conflict from Ukraine, continuous and unpredictible threats of ISIS group, various misunderstandings in the Middle East etc.). Therefore, by doing a very fast analysis on these changes of the international environment, it turns out that, in an allied context, the national defense of a state is extremely important and can be assured at a maximum level only by integrating it into a mechanism provided by a international alliance.

A very well understanding of the national defense role in an allied context and still having limited capabilities to provide a fully integrated security, the Romanian state has acquitted itself from the first negotiations in which took part, to assume a considerable number of functions within international missions, within international staff commands of these missions, as well as assuming several abroad permanent positions from international military command structures and also assume some $\mathrm{UN}$ and EU observer posts in areas with a high potential for conflict.

For example, we list some of the international missions to which Romania was or is a contributing state, precisely to respect the principles of national defense in an allied context: Resolute Support Mission in Afghanistan (RSM), European Union Force Althea (EUFOR Althea) in Bosnia and Herzegovina (with the staff command in Sarajevo), EULEX Kosovo (a surpport mission to the rule of law in this region), ensuring the basic structure of the peacekeeping mission in Lebanon (UNIFIL - taking into account the Israeli-Lebanese conflict), EUMM (European Union mission of humanitarian assistance, mediation, monitoring and financial support in Georgia), 
the staff providing for UN observer positions in South Sudan (UNMISS), UN Mission in the Democratic Republic of Congo (MONUSCO), the active participation of the EU in the " $5+2$ " negotiation format and through the assistance mission at EU border rlating to the Transnistrian conflict, the refugees protection in Chad, the staff providing for the Military Observation Group from India and Pakistan (UNMOGIP) etc.

Through the defense policy practised by Romanian state in the allied context, we could affirm that we are permanently prepared to respond to almost any new type of unwanted event that may occur in the international security environment and that, through the joint effort of members of the international alliance of which we are part and by using the necessary capacities, we are able to ensure the security of the citizens to a desirable level.

Based on the same discussion of how to exercise the national defense of a state in a well-defined ally context, we must specify that, besides other NATO and EU member states (which are not so many), Romania cannot defend alone, by itself, in the situation of an attack carried out on more many action directions by another state with higher capabilities. Therefore, in a such situation, Romania cannot fully guarantee its security and citizens security by its own means.

In this regard, national security policies must adhere to the principles of collective and indivisible security, to be based on NATO and EU membership status, on bilateral relations strengthening with various partners, on regional cooperation and on developing of the defense capabilities that are needed to be interoperable, deployable, sustainable and able to cover the requirements of all missions. Thus, in order to achieve all these aspects, Romania must take into account the following:

- the fulfilling of obligations deriving from the Constitution and laws;
- the fulfilling of specified obligations in order to ensure the collective security and defense within the North Atlantic Alliance;

- the continuous and proactive participation in the EU's Common Security and Defense Policy;

- the respecting of commitments that Romania has towards other states, organizations and international treaties;

- the cooperation with the states of the Partnership for Peace and with the states of the Euro-Atlantic Partnership;

- the strengthening of the position of local security and stability provider;

- the defense industry revitalizing and the ensuring of necessary investments in the economy segments that produce subassemblies for this industry;

- the compliance with the international law regulations imposed by the international environment but also by the organizations with legal status that have an serious impact on global security.

It is important to add that, in the current context related to the exercise of the defense of the states under the umbrella of an alliance or alliances, Romania being included in this discussion, we must also consider the efforts made by these states in the fight against cyber attacks (quite virulent in some cases), amid the amplification of these types of attacks. In order to highlight the need to give a special attention to these cyber attacks, we must mention that, by their use by different people (usually with a very advanced training in this field), organizations or even states, both security as well as the economy of a state could be affected, considering that they heavily rely on: communications, infrastructure/critical infrastructure, transport (both informational and classical, realized with various mobile means), energy supply etc.

Just to avoid the use against it of unwanted cyber incursions, through the strategy for a safe and secure information society to which the Romanian state also contributes, the EU addresses both the criminality based on internet and crimes of 
various types produced through the online environment, as it seems that, these have gradually become redoubtable weapons against national economies, policies and defenses, mainly belonging to modern, developed or developing states.

In conclusion, we mention that a state could provide full security to its citizens through a properly planned, organized and managed defense. However, in the event of an unpredictable attack, carried out simultaneously by multiple ways by a superior enemy (both in terms of troops and capabilities), it is possible like the respective state to may face a series of problems that will put it in the situation to no longer fully protect its citizens. Given this asect, we consider that the joining to international security organizations and the developing of the defense under their umbrella, so in an allied context, can only be beneficial for all partner states and are designed to maintain a safe and implicitly a security climate and, finally, to maintain the peace.

\section{The role and the importance of} human resource development in the context of national defence

In order to know the role of the human resource in the context of national defence, we must constantly report on defining the notion of defence. Having in mind that the defence represents the need of a state, of an entity or of a person to be out of danger, this need being accompanied by the existence of the feeling of trust and tranquillity arising as a result of the absence of hazards of any kind, it results in an extreme bond of close and an obvious interdependence between the two, let's call them "entities".

As everyone knows, the human resource has always been, and still it is the most important element of the proper functioning of any system, whether it be state or private, or a company consisting of both state capital and private equity. Of course, neither the Army, as part of a system, namely the defence system, public order, national security and judicial authority, can make an exception from this aspect. Thus, there can be no optimum and progressive functioning of the military system, except in the conditions of its generation by a very good quality human resource, very well prepared and very well educated across all that means national belonging and values such as: morality, verticality and dignity.

It is obvious that a superior preparation and training of the human resource (no matter of how theese are carried out) will have as a result the implementing of a high level of national defence, a level that could provide the state security in front of various threats. Thus, the human resource, through the preparation to which it is welded during military studies and courses (but also civil, in some cases), that are followed, has to acquire a wider range of information and knowledge which, finally, put into practice could lead to the best possible progress of activities related to the national defence.

Given the complexity of the area related to the national defence, it is necessary that during studies and courses, the human resource within the military institution should deepen the knowledge in all areas (from history to elements related to strategic planning and endowment, passing through the knowledge related to economy, sociology and others), as all these will constitute important reference data, which put together form the information base for good management of various defence subdomains.

The need to be always aware of the permanent changes of the security environment makes our country to prepare specialists who have to be able to provide, at any time, specialised information which can ensure the taking of the best decisions by those with responsibilities in the field, by those who are responsible in the management of various situations, more sensitive cases with extensive security implications.

Thus, as we well know, annually, are sent abroad, to various forms of studies and 
training organised by NATO member countries, officers and non commissioned officers from various military structures of the Romanian Army, especially from the military units that are already operationalised or from military units that follow to be operationalised. Obviously, for Romania, this issue can only be a beneficial one, resulting in the maintaning of the national defence at a very high level and, why not, even upgrading it.

Another element linked to the connection between maintaining a high level of the national defence and the development level of the human resource of the Army, is the necessity of maximum "exploiting" of the knowledge that soldiers accumulate along the deployment of a mission that includes the permanent post abroad. Here, we must point out that, since it is a member of NATO and the EU, Romania has negotiated and obtained permanent posts abroad in all the headquarters of these structures and in all areas of activity, from J1 - Personnel Management to J8 Planning and Endowment in the field of defence. This aspect is also due to the fact that Romania is very well seen and appreciated inside the two international organisations, precisely because of the qualities and performances that the human resource holds and has proven over time and during missions. Also, we must note that due to devotion to the image of the country in the general framework of international organisations, the Romanian militaries have engaged and are still involved in carrying out at the highest level the tasks from job description when they perform a three or four years mandate specific to the permanent post abroad, and the excellent results obtained by them are always materialised in the service assessments/appreciations, but also in the appreciation certificates or diplomas obtained at the end of the mandate.

To return to the link between the national defence and the human resource that carries out a mission under the form of a permanent post abroad and not only, as temporary missions also have their contribution to the development of the military institution, we must specify that if the military institution makes full use of all knowledge accumulated by our militaries during the mission abroad, it creates those desirable situations that could lead to the development of both the system and the human factor, and ultimately, this twodimensional development can only ensure a very high level of the national defence. This aspect has in view both the continuous development of the international environment specific to military missions and the development of Romanian military institution.

\section{REFERENCES}

European Union. (2004). The Establishing Treaty of a Constitution for Europe, Chapter II, Article 1-41, Section 7, Chapter VII, Article III-329, Point 1: European Union member states.

Ministry of National Defence. (2018). The Defence Planning Directive 2018-2027.

Moştoflei, C., \& Duţu, P. (2004). Collective defence and national defence. Bucharest, Romania: "Carol I" National Defense University Publishing House.

Romania the Presidential Administration. (2015). National Defense Strategy 20152019: a Strong Romania within Europe and the World. Bucharest, available at: https:// www.presidency.ro/ files/ userfiles/National_Defense_Strategy_2015_2019.pdf, accessed on 27 July 2019. 
Romanian Government. (2016). The Military Strategy. Bucharest: Official Gazette, no. 789.

Romanian Government. (2017). The Governance Programme for the period 2017 2020, available at: http://www.cdep.ro/pdfs/guv201706/Program de Guvernare.pdf, accessed on 27 July 2019.

Romanian Government. (2017). White Defence Charter. Bucharest: Official Gazette.

Romanian Government. (2018). The Governance Programme for the period 2018 2020, available at: http://gov.ro/fisiere/pagini_fisiere/ PROGRAMUL_DE_GUVERNARE_ 2018-2020.pdf, accessed on 27 July 2019.

Romanian Parliament. (2015). Law No. 203, elaborated and approved. Bucharest: Official Gazette.

United Nations Organisation. (1945). The Chart of the United Nations Organisation. Article 51, San Francisco, California, USA: United Nations Organisation member states.

United Nations Organisation. (1949). The North Atlantic Treaty. Washington, D.C., USA: United Nations member states. 